\title{
Eribulin shows high concentration and long retention in xenograft tumor tissues
}

\author{
Michiko Sugawara $^{1} \cdot$ Krista Condon $^{2} \cdot$ Earvin Liang $^{2} \cdot$ Christopher DesJardins $^{2}$. \\ Edgar Schuck $^{2} \cdot$ Kazutomi Kusano $^{3} \cdot$ W. George Lai ${ }^{2}$
}

Received: 25 May 2017 / Accepted: 16 June 2017 / Published online: 29 June 2017

(c) The Author(s) 2017. This article is an open access publication

\begin{abstract}
Purpose Eribulin, a synthetic analog of the natural product halichondrin $\mathrm{B}$, is a microtubule dynamics inhibitor. In this study, we report the pharmacokinetic profiles of eribulin in mice, rats, and dogs following intravenous administrations with optimized and validated bio-analytical methods.

Methods Eribulin was administered at 0.5 and $2 \mathrm{mg} / \mathrm{kg}$ in mice, 0.5 and $1 \mathrm{mg} / \mathrm{kg}$ in rats, and $0.08 \mathrm{mg} / \mathrm{kg}$ in dogs. Tumor and brain penetration of eribulin was also evaluated in LOX human melanoma xenograft models. Concentrations in plasma, tumor, and brain were measured by the LC-MS/MS method.

Results The profiles of eribulin were characterized by extensive distribution, moderate clearance, and slow elimination in the three species. The pharmacokinetics are linear in mice and rats. In xenograft mice, the penetration into the brain was low, as expected, since eribulin is a P-glycoprotein substrate. In contrast to disposition in brain, the exposure of eribulin was approximately 20-30 times higher in tumor than that in plasma and half-lives were $17.8-35.9 \mathrm{~h}$ after both single and multiple dose regimens.

Conclusions Eribulin was distributed rapidly and eliminated slowly in mice, rats, and dogs. The exposure of eribulin was approximately 20-30 times higher in tumor than in
\end{abstract}

Michiko Sugawara

m-sugawara@hhc.eisai.co.jp

1 Medical Communication Section, Medical Division, Eisai Co., Ltd., Nishigoken-cho 13-1, Shinjuku-ku, Tokyo 162-0812, Japan

2 DMPK-Andover, Biopharmaceutical Assessments, Eisai Inc., Ltd., Massachusetts, USA

3 Tsukuba Research Laboratories, Eisai Co., Ltd., Ibaraki, Japan plasma in xenograft mice. These results might be caused by eribulin's mechanism of action including increased perfusion in tumor by vascular remodeling effect.

Keywords Eribulin · Tumor · Pharmacokinetics · Xenograft

$\begin{array}{ll}\text { Abbreviations } \\ \text { ABCB } & \text { ATP-binding cassette subfamily B } \\ \text { ABCC } & \text { ATP-binding cassette subfamily C } \\ \text { AUC } & \begin{array}{l}\text { Area under the plasma concentration versus } \\ \text { time curve }\end{array} \\ \text { CL } & \text { Total body clearance } \\ C_{\text {max }} & \text { Maximum plasma concentration } \\ \text { IS } & \text { Internal standard } \\ \text { LC-MS/MS } & \text { Liquid chromatography-tandem mass } \\ & \text { spectrometry } \\ \text { MRT } & \text { Mean residence time extrapolated to infinity } \\ m / z & \text { Mass-to-charge ratio } \\ \text { P-gp } & \text { P-glycoprotein } \\ \text { PK } & \text { Pharmacokinetic } \\ \text { Q2Dx3 } & \text { Once every } 2 \text { days for three doses } \\ t_{1 / 2} & \text { Terminal half-life } \\ V_{\text {ss }} & \text { Volume of distribution at the steady state }\end{array}$

\section{Introduction}

Eribulin (Fig. 1), a synthetic analog of the natural product halichondrin $\mathrm{B}$, is currently being used as an anticancer agent. Eribulin has sub-nanomolar growth inhibitory activities in vitro against numerous human cancer cell lines as well as marked in vivo activities at $0.1-1 \mathrm{mg} / \mathrm{kg}$ against human xenografts via irreversible mitotic blockade $[1,2]$. Eribulin's mode of action is distinct from other 
Fig. 1 Chemical structures of eribulin and IS. a Eribulin. Molecular weight 729.90. b IS. Molecular weight 730.88 (a)

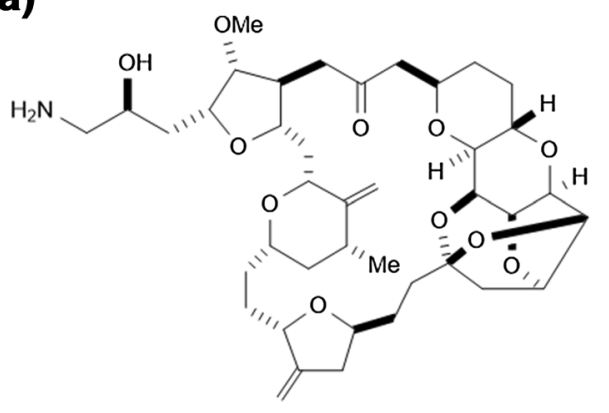

(b)

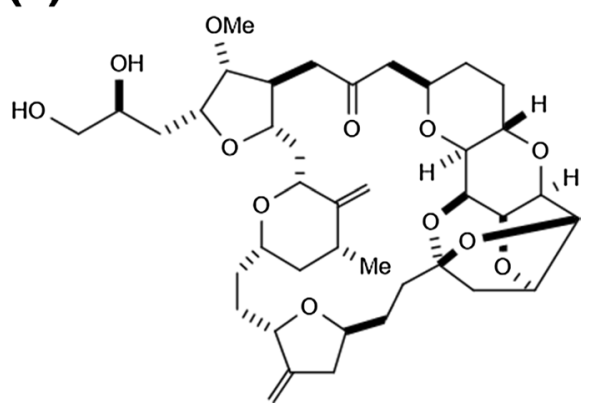

tubulin inhibitors, and it involves binding to specific sites on the growing positive ends of microtubules to inhibit their growth [2-4]. Eribulin also induces vascular remodeling, suppresses migration and invasion of cancer cells, and reverses the epithelial-to-mesenchymal transition in cancer cell lines [5-7].

Eribulin has been approved for treatment of metastatic breast cancer who has previously received at least two chemotherapeutic regimens including an anthracyclines and a taxane and unresectable or metastatic liposarcoma who have received a prior anthracycline-containing regimen in the US. Phase III trials revealed improvement in overall survival in such patients treated with eribulin, compared with the conventional treatments [8-10]. Pharmacokinetic $(\mathrm{PK})$ profiles of eribulin have been reported in clinical studies. The PK profile of eribulin was characterized by an extensive volume of distribution, slow-tomoderate clearance, and slow elimination. Area under the plasma concentration versus time curve (AUC) and maximum plasma concentration $\left(C_{\max }\right)$ increased in almost direct proportion to the dose of eribulin $\left(0.25-4 \mathrm{mg} / \mathrm{m}^{2}\right)$ [11-13]. A mass balance study with radiolabeled eribulin in patients with advanced solid tumors showed that more than $80 \%$ of administered radioactivity was excreted in feces, where unchanged eribulin was $61.9 \%$, whereas renal excretion of eribulin was $8.9 \%$ [14]. These results indicate that metabolism and renal clearance contribute to the elimination of eribulin in a minor way.

Preclinical studies have shown that higher brain penetration of eribulin was observed in ATP-binding cassette subfamily B (ABCB) member 1a-deficient mice, a subpopulation that naturally lacks the ABCB1a-encoded P-glycoprotein (P-gp), compared with the wild-type mice, suggesting that eribulin is likely to be a P-gp substrate [15].

The efficacy and toxicity of anti-cancer drugs in the treatment of tumors are highly dependent on the ability of the drugs to distribute into tumor tissue at the optimal therapeutic dose. In a preclinical study, eribulin exhibited wide in vivo therapeutic windows [1]. In phase II and III clinical studies, eribulin showed a significant and clinically meaningful improvement in overall survival of patients with metastatic breast cancer compared with treatment of physician's choice [8], with manageable safety profiles. The most common grade 3/4 adverse events (AE) were neutropenia $(45.2 \%)$, leukopenia $(13.9 \%)$, and asthenia/fatigue $(8.8 \%)$. Although peripheral neuropathy was a common AE leading to treatment discontinuation, the peripheral neuropathy typically improved in later cycles. Thus, eribulin showed balanced profile of efficacy and safety in preclinical and clinical settings.

There has not been a report of preclinical PK profiles of eribulin in tumor-bearing mice or in other preclinical species. In this study, PK profiles of eribulin in mice, rats, and dogs following intravenous administration were investigated with optimized and validated bio-analytical methods. In addition, brain and tumor penetration of eribulin were evaluated in a xenograft model to further characterize antitumor activity in terms of its disposition.

\section{Materials and methods}

\section{Chemicals and reagents}

Eribulin and the internal standard (IS, ER076349) were synthesized at Eisai Research Institute (ERI, Andover, MA) (Fig. 1). All reagents used in this study were of analytical grade. Mouse, rat, and beagle control plasma containing EDTA as the anticoagulant were purchased from BioreclamationIVT (Westbury, NY), Cocalico Biologicals Inc. (Reamstown, PA), or Biological Specialty Corp. (Colmar, PA).

\section{PK studies in mice, rats, and dogs}

Male BALB/c mice (22-24 g) and jugular vein cannulated male Sprague-Dawley rats (226-250 g) were purchased from Charles River Laboratories (Wilmington, MA). Male purebred beagle dogs (approximately $8 \mathrm{~kg}$ and 6-8 months old) were selected from the stock colony in Covance (Princeton, NJ). Dosing solutions of eribulin were freshly prepared by dissolving eribulin in deionized water, and 
administered intravenously via tail veins in mice and rats and cephalic veins in dogs. The doses studied were 0.5 and $2 \mathrm{mg} / \mathrm{kg}$ in mice, 0.5 and $1 \mathrm{mg} / \mathrm{kg}$ in rats, and $0.08 \mathrm{mg} / \mathrm{kg}$ in dogs. According to the conversion of doses based on body surface area [16], the doses in this study would be equivalent to the $1.4 \mathrm{mg} / \mathrm{m}^{2}$ clinical dose of eribulin.

Blood specimens were collected from each species at predetermined time points $(5,15,30 \mathrm{~min}$, and 1, 2, 4, 8, 12, 24 , and $48 \mathrm{~h}$ for mice; 5, 7.5, 10, 15, 25, $40 \mathrm{~min}$, and 1, 2, $4,6,8,12,24$, and $48 \mathrm{~h}$ for rats; 5, 7.5, 10, 15, 25, $40 \mathrm{~min}$, and $1,2,4,6,8,12,24,36$, and $48 \mathrm{~h}$ for dogs) and stored in tubes containing sodium EDTA as anticoagulant. Plasma levels of eribulin from all species were determined by liquid chromatography-tandem mass spectrometry (LC-MS/ MS).

All the studies using laboratory animals were approved either by the Eisai (Andover, MA) Institutional Animal Care and Use Committees (IACUCs) or the IACUC of the contract research organization that conducted the study, and adhered to all of the applicable institutional and governmental guidelines for the humane care and use of laboratory animals.

\section{Tumor and brain penetration in xenograft model}

Tumor and brain penetration of eribulin was evaluated in LOX human melanoma xenograft models as previously described [1]. In brief, female Ncr LOX tumor-bearing nu/ nu mice ( $n=3 /$ time point/dose group) were given a single 1.0 or $2.0 \mathrm{mg} / \mathrm{kg}$ intravenous dose of eribulin or 0.5 or $1.0 \mathrm{mg} / \mathrm{kg}$ intravenously once every 2 days for three doses (Q2Dx3). Blood, tumor, and brain tissues were collected from each animal at predetermined time points $(15,30 \mathrm{~min}$, and $1,2,4,8,12,24$, and 36 h postdose). Concentrations of eribulin in brain, tumor, and plasma were determined by LC-MS/MS.

\section{Analysis of plasma samples}

Analysis of eribulin in mouse, rat, and dog plasma was performed using a validated LC-MS/MS method with modifications for human plasma as previously described [17]. In brief, an aliquot of plasma sample was mixed with $500 \mathrm{ng} / \mathrm{mL}$ of IS and extracted with a C8 SPE cartridge. The eluent was collected and evaporated to dryness in a $35{ }^{\circ} \mathrm{C}$ water bath under nitrogen, and then reconstituted with methanol, water, and formic acid (50:50:1; by volume). Each sample was analyzed on a Quattro Ultima Micromass triple quadrupole mass spectrometer (Micromass Limited, Beverly, MA) using electrospray ionization under positive ion mode. Eribulin was monitored at precursor ion as a mass-to-charge ratio $(\mathrm{m} / \mathrm{z})$ at 730.4 and product ion $\mathrm{m} / \mathrm{z}$ at 712.5 , and IS was monitored at precursor ion $\mathrm{m} / \mathrm{z}$ at 731.4 and product ion $\mathrm{m} / \mathrm{z}$ at 681.5 . Mobile phases $\mathrm{A}$ and $\mathrm{B}$ consisted of acetonitrile, water, and formic acid (13:87:0.1; by volume), and acetonitrile, tetrahydrofuran, and formic acid (70:30:0.1; by volume), respectively. Aliquots were injected onto a C18 MetaChem Polaris $3 \mu \mathrm{m}$, $30 \mathrm{~mm} \times 2.0 \mathrm{~mm}$ column (Agilent, Santa Clara, CA). Retention times for eribulin and IS were 4.2 and $4.5 \mathrm{~min}$, respectively. Calibration and quality control standards were freshly prepared in each analytical run using appropriate blank plasma. Peak areas of eribulin and IS were calculated and integrated using QuanLynx 3.5 (Micromass Limited; Beverly, MA).

\section{Analysis of brain and tumor samples}

LC-MS/MS analyses of eribulin in brain and tumor samples were performed. In brief, tumor or brain tissue was prepared by homogenizing the specimen with three times its weight of phosphate-buffered saline using a Polytron PT 1200 tissue homogenizer (Kinematica AG, Lucern, Switzerland). The brain or tumor homogenate was vortexed with IS and $0.1 \mathrm{~N}$ sodium hydroxide in a polypropylene tube. Following addition of nano-pure water and further mixing, a solution of ethyl acetate, methanol, and ethanol (90:5:5, by volume) was added into the mixture, shaken horizontally, and then centrifuged at $4{ }^{\circ} \mathrm{C}$. An aqueous phase of the mixture was frozen in a dry ice/isopropyl alcohol bath to retrieve the organic phase. The collected organic phase was transferred to a polypropylene tube and dried under nitrogen at $35^{\circ} \mathrm{C}$. The residue was then reconstituted with methanol/water ( $1: 1$, by volume) containing $0.1 \%$ formic acid. A Shimadzu Co-Sense high-performance liquid chromatography system (Shimadzu Scientific Instruments, Columbia, MD) was used for gradient elution of eribulin. Aliquots were injected onto a Polaris C18-A column $(30 \mathrm{~mm} \times 2.0 \mathrm{~mm})$ with a constant temperature of $30{ }^{\circ} \mathrm{C}$. Retention times for eribulin and IS were approximately $4.5 \mathrm{~min}$ and $4.6 \mathrm{~min}$, respectively. Detection of the eluents was conducted using an API4000 triple quadrupole mass spectrometer (Sciex, Framingham, MA) using electrospray ionization under positive ion mode. Eribulin was monitored at precursor ion $m / z 730.5$ and product ion $m / z 712.5$, and the IS was monitored at precursor ion $\mathrm{m} / z, 731.5$ and product ion $\mathrm{m} / \mathrm{z} 681.5$.

\section{PK analysis}

PK parameters of eribulin were estimated through noncompartmental analysis using WinNonLin 4.0.1 (Certara, Princeton, NJ). Eribulin plasma concentrations below the quantification limit were left blank at time 0 and treated as 0 at other time points. Nominal time was used for all analyses with the exception of actual time deviations greater than 
$10 \%$ for sampling time prior to $24 \mathrm{~h}$, or $1 \mathrm{~h}$ for sampling time post $24 \mathrm{~h}$. The actual time was used for those cases. For mice PK, the parameters were calculated based on mean concentration of each time point, because the blood at each point was collected from independent animals. Plasma concentrations and PK parameters of eribulin are expressed as mean or mean \pm standard deviation (SD) using Excel 2000 (Microsoft, Redmond, WA) in rats and dogs. Penetration of eribulin into tumor and brain was assessed by the tumor penetration index (TPI) and brain penetration index (BPI), respectively, which were calculated as the ratio of the AUC in the tumor or brain to that in the plasma.

\section{Statistical analysis}

Statistical analysis was performed using SigmaStat 2.03 (SPSS Inc.; Chicago, IL). One-way analysis of variance was used to examine the concentration effects on PK parameters among groups with $P$ value less than 0.05 considered statistically significant. Outliers when applicable were rejected based on the Dixon's criteria [18].

\section{(a)}

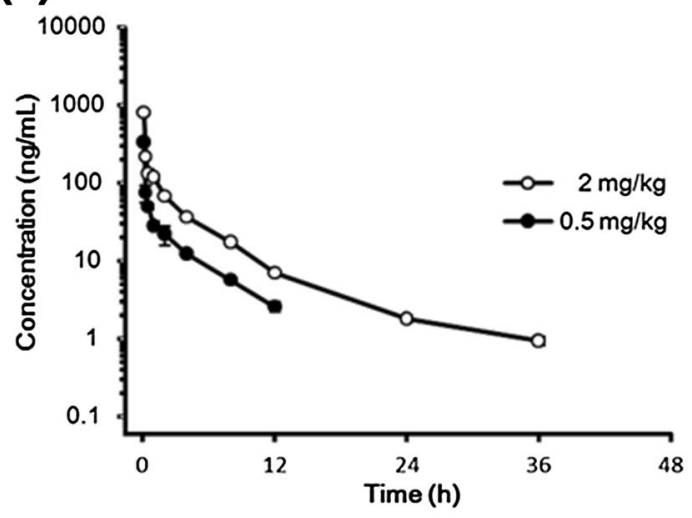

(c)

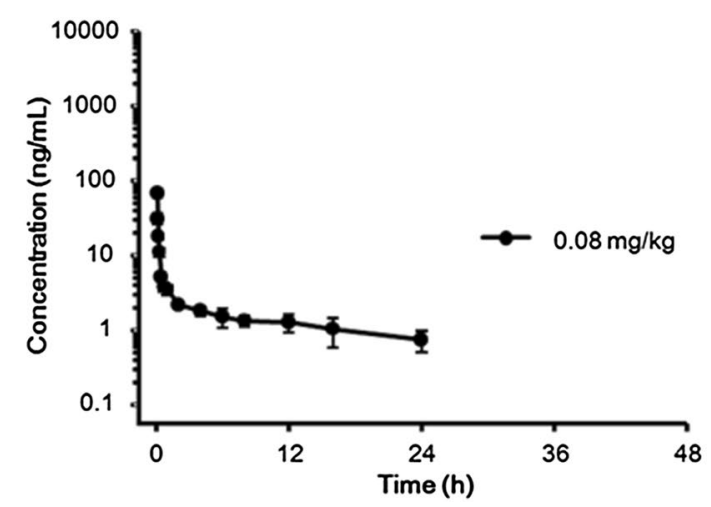

\section{Results}

\section{Linearity and lower limit of quantification}

Plasma levels of eribulin were linear from 0.5 to $500 \mathrm{ng} /$ $\mathrm{mL}$ for all species studied. Regression coefficients of the calibration curves were greater than 0.979 in all matrices investigated. The quantification limit was $0.5 \mathrm{ng} / \mathrm{mL}$ for plasma and $2 \mathrm{ng} / \mathrm{g}$ for tumor and brain, with the exception of the multiple dose study, which was $4.0 \mathrm{ng} / \mathrm{g}$ for brain samples.

\section{PK characteristics of eribulin in animals}

Figure 2 shows the mean concentration-time profiles of eribulin in plasma for the three species. PK parameters are listed in Table 1.

The distribution of eribulin was extensive in all animal species tested. In mice, the volume of distribution at the steady state $\left(V_{\mathrm{ss}}\right)$ of eribulin in mice was 6.44 or $12.2 \mathrm{~L} / \mathrm{kg}$ when administered at 0.5 or $2 \mathrm{mg} / \mathrm{kg}$, respectively. The $V_{\mathrm{ss}}$ at $0.5 \mathrm{mg} / \mathrm{kg}$ might be underestimated, because the profile was

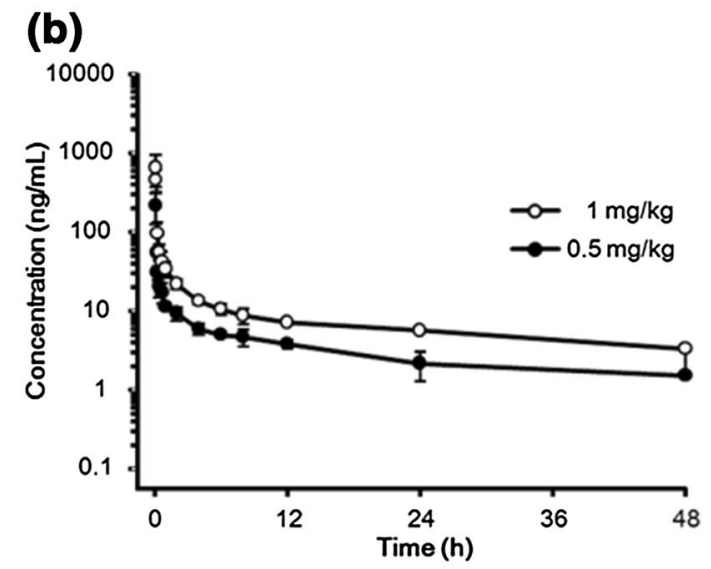

Fig. 2 Plasma concentration versus time profiles of eribulin following a single intravenous administration of eribulin. a Mouse: data are expressed as mean $\pm \mathrm{SD}(n=3)$. b Rat: data are expressed as mean $\pm \mathrm{SD}(n=3)$. $\mathbf{c}$ Dog: data are expressed as mean $\pm \operatorname{SD}(n=4)$ 
Table 1 PK parameters of plasma in normal mouse, rat, and dog following a single intravenous administration of eribulin

\begin{tabular}{llclll}
\hline Parameters & \multicolumn{2}{l}{ Mouse $N=3 /$ time point } & Rat, $N=3$ & Dog, $N=4$ \\
\hline Dose $(\mathrm{mg} / \mathrm{kg})$ & 0.5 & 2 & 0.5 & 1 & 0.08 \\
$t_{1 / 2}(\mathrm{~h})$ & 3.55 & 6.88 & $15.9 \pm 7.1$ & $27.9 \pm 4.1$ & $21.9 \pm 9.5$ \\
$\mathrm{MRT}_{\text {inf }}(\mathrm{h})$ & 3.05 & 4.38 & $20.2 \pm 14.8$ & $27.3 \pm 4.1$ & $21.5 \pm 11.9$ \\
$\mathrm{AUC}_{0-\text { last }}(\mathrm{ng} \mathrm{h} / \mathrm{mL})$ & 223.2 & 707.0 & $212.3 \pm 49.3$ & $496.4 \pm 80.6$ & $64.5 \pm 20.1$ \\
$\mathrm{AUC}_{0-\text { inf }}(\mathrm{ng} \mathrm{h} / \mathrm{mL})$ & 236.4 & 716.2 & $259.6 \pm 69.6$ & $628.4 \pm 83.9$ & $82.2 \pm 27.4$ \\
$\mathrm{CL}(\mathrm{L} / \mathrm{h} / \mathrm{kg})$ & 2.14 & 2.79 & $2.04 \pm 0.65$ & $1.61 \pm 0.20$ & $1.06 \pm 0.36$ \\
$V_{\text {ss }}(\mathrm{L} / \mathrm{kg})$ & 6.44 & 12.2 & $36.3 \pm 21.0$ & $44.1 \pm 10.7$ & $20.4 \pm 5.5$ \\
\hline
\end{tabular}

Data expressed in mean (for mouse) or mean $\pm \mathrm{SD}$ (for rat and dog)

Table 2 PK parameters in a LOX human melanoma xenograft model

\begin{tabular}{|c|c|c|c|c|c|c|c|c|c|c|c|c|}
\hline \multirow{2}{*}{$\begin{array}{l}\text { Dose }^{\mathrm{a}} \text { regimen } \\
\text { Specimen }\end{array}$} & \multicolumn{3}{|c|}{$\begin{array}{l}1.0 \mathrm{mg} / \mathrm{kg} \\
\text { Single dose }\end{array}$} & \multicolumn{3}{|c|}{$\begin{array}{l}2.0 \mathrm{mg} / \mathrm{kg} \\
\text { Single dose }\end{array}$} & \multicolumn{3}{|c|}{$\begin{array}{l}0.5 \mathrm{mg} / \mathrm{kg} \\
\text { Q2Dx3 } 3^{\mathrm{b}}\end{array}$} & \multicolumn{3}{|c|}{$\begin{array}{l}1.0 \mathrm{mg} / \mathrm{kg} \\
\mathrm{Q} 2 \mathrm{Dx} 3^{\mathrm{b}}\end{array}$} \\
\hline & Plasma & Brain & Tumor & Plasma & Brain & Tumor & Plasma & Brain & Tumor & Plasma & Brain & Tumor \\
\hline \multicolumn{13}{|l|}{ Parameters } \\
\hline$C_{\max }(\mathrm{ng} / \mathrm{mL}$ or $\mathrm{g})$ & NA & 9.75 & 323.4 & NA & 31.9 & 515.3 & NA & 4.20 & 153.6 & NA & 11.5 & 407.9 \\
\hline$t_{\max }^{\mathrm{c}}(\mathrm{h})$ & NA & 0.25 & 0.25 & NA & 0.5 & 0.5 & NA & 0.5 & 0.25 & NA & 0.5 & 1.0 \\
\hline $\mathrm{AUC}_{0 \text {-inf }}(\mathrm{ng} \mathrm{h} / \mathrm{mL}$ or $\mathrm{g})$ & 365.2 & 47.8 & 6294.3 & 796.5 & 361.9 & 18564.9 & 161.8 & $\mathrm{NC}$ & 5500.9 & 308.6 & $\mathrm{NC}$ & 8820.8 \\
\hline $\mathrm{AUC}_{0 \text {-inf }} / \mathrm{D}^{\mathrm{d}}(\mathrm{ng} \mathrm{h} / \mathrm{mL}$ or $\mathrm{g} / \mathrm{D})$ & 413.2 & NA & NA & 450.5 & NA & NA & 366.1 & NA & NA & 349.1 & NA & NA \\
\hline$t_{1 / 2}(\mathrm{~h})$ & 3.7 & 6.0 & 17.8 & 5.1 & 32.4 & 30.4 & 2.2 & $\mathrm{NC}$ & 35.9 & 2.4 & NA & 19.0 \\
\hline $\mathrm{CL}(\mathrm{L} / \mathrm{h} / \mathrm{kg})$ & 2.42 & NA & NA & 2.22 & NA & NA & 2.73 & NA & NA & 2.86 & NA & NA \\
\hline$V_{\mathrm{ss}}(\mathrm{L} / \mathrm{kg})$ & 8.03 & NA & NA & 6.79 & NA & NA & 7.57 & NA & NA & 7.41 & NA & NA \\
\hline BPI (AUC Arainf $\left._{0-\text { inf }} / \mathrm{AUC}_{0-\text { inf }}^{\text {plasma }}\right)$ & \multicolumn{3}{|l|}{0.131} & \multicolumn{3}{|l|}{0.454} & \multicolumn{3}{|l|}{$\mathrm{NC}$} & \multicolumn{3}{|l|}{$\mathrm{NC}$} \\
\hline TPI (AUC A tumf $\left._{0 \text {-inf }}^{\text {tum }} / \mathrm{AUC}_{0-\text { inf }}^{\text {plasma }}\right)$ & \multicolumn{3}{|l|}{17.233} & \multicolumn{3}{|l|}{23.308} & \multicolumn{3}{|l|}{33.999} & \multicolumn{3}{|l|}{28.581} \\
\hline
\end{tabular}

$N A$ not applicable, $N C$ not calculated due to insufficient data at the terminal phase

a Dose of eribulin is expressed in equivalents of the mesylate salt

b Once every 2 days for three doses

c The time after administration of eribulin when the maximum plasma concentration is reached

${ }^{\mathrm{d}} \mathrm{D}$ means the free base of eribulin

not characterized properly. In rats, the mean $V_{\mathrm{ss}}$ averaged 36.3 or $44.1 \mathrm{~L} / \mathrm{kg}$ when 0.5 or $1 \mathrm{mg} / \mathrm{kg}$ of eribulin, respectively, was administered, with no statistical difference between the two doses $(P=0.597)$. In dogs, the mean $V_{\mathrm{ss}}$ was $20.4 \mathrm{~L} / \mathrm{kg}$ following administration of $0.08 \mathrm{mg} / \mathrm{kg}$ of eribulin, with no major inter-day fluctuation (data not shown).

Total body clearance (CL) of eribulin was moderate in all species tested. In mice, the CL was 2.14 or $2.79 \mathrm{~L} / \mathrm{h} / \mathrm{kg}$ at a 0.5 or $2 \mathrm{mg} / \mathrm{kg}$ dose, respectively. In rats, the CL was 2.04 or $1.61 \mathrm{~L} / \mathrm{h} / \mathrm{kg}$ at a 0.5 or $1 \mathrm{mg} / \mathrm{kg}$ dose, respectively, with no statistical difference $(P=0.335)$ between the two doses. In dogs, the CL was $1.06 \mathrm{~L} / \mathrm{h} / \mathrm{kg}$ when administered $0.08 \mathrm{mg} / \mathrm{kg}$ of eribulin.

Elimination of eribulin was slow in all species studied. In mice, the terminal half-lives $\left(t_{1 / 2}\right)$ were 3.6 or $6.9 \mathrm{~h}$ after 0.5 or $2 \mathrm{mg} / \mathrm{kg}$, respectively. In rats, the $t_{1 / 2}$ were 15.9 or $27.9 \mathrm{~h}$ after 0.5 or $1 \mathrm{mg} / \mathrm{kg}$, respectively, and there was no statistical difference between these two doses $(P=0.064)$.
Similar values were obtained in dogs. Overall, the results suggest linear pharmacokinetics of eribulin in the dose range tested. Compartmental analysis (data not shown) in general supported the above observation.

\section{Tumor and brain penetration of eribulin in xenograft model}

The data in LOX tumor-bearing mice are summarized in Table 2 and depicted in Fig. 3.

Plasma PK profiles of eribulin following single and multiple intravenous administrations (Q2Dx3) to LOX tumor-bearing mice were characterized by extensive distribution $\left(V_{\mathrm{ss}}: 6.79-8.03 \mathrm{~L} / \mathrm{kg}\right)$, moderate clearance (CL: $2.22-2.86 \mathrm{~L} / \mathrm{h} / \mathrm{kg})$, and moderate elimination $\left(t_{1 / 2}\right.$ : 2.2-5.1 h).

Penetration of eribulin into the tumors was fast $\left(t_{\max }=0.25-1.0 \mathrm{~h}\right)$. The calculated TPI showed that 
(a)

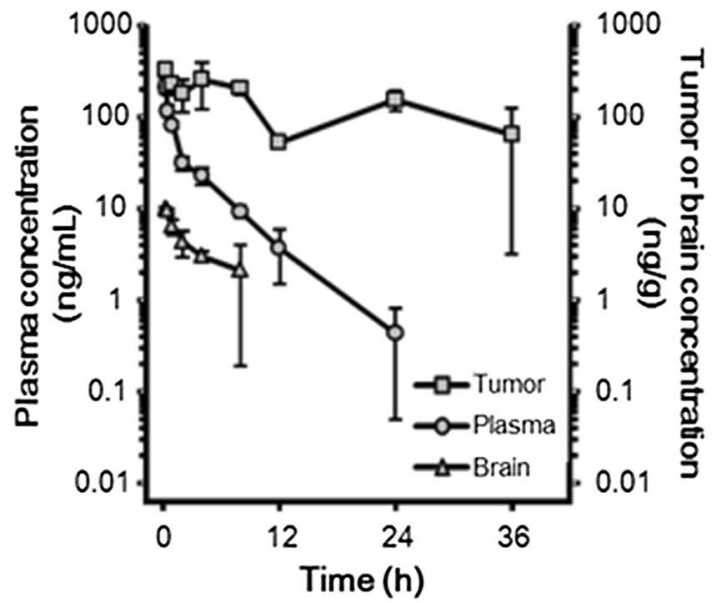

(c)

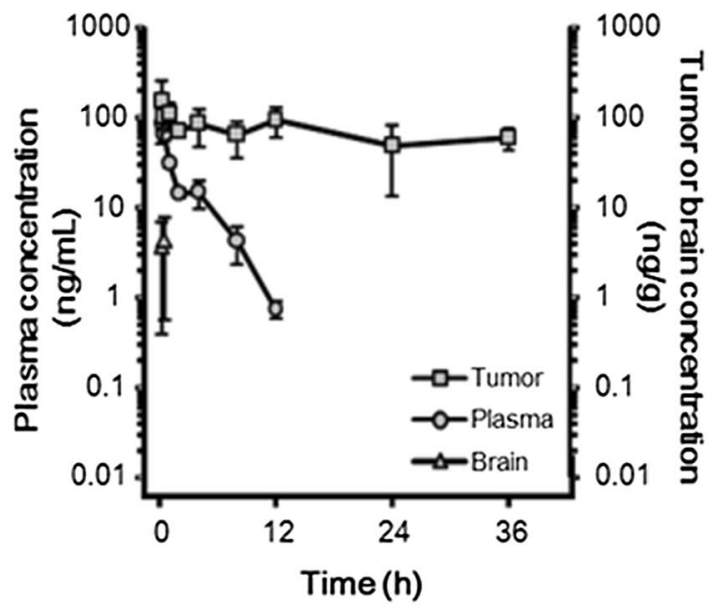

Fig. 3 Tumor, brain, and plasma levels of eribulin in LOX human melanoma xenograft model following intravenous administration of eribulin. a Single $1.0 \mathrm{mg} / \mathrm{kg}$. b Single $2.0 \mathrm{mg} / \mathrm{kg}$. c Q2Dx3*0.5 mg/kg.

exposures to eribulin were approximately 20-30 times higher in tumor than in plasma after both single and multiple dose administration. The TPI following multiple dosing was slightly higher than that observed after single dosing, but it is not possible to conclude that there was accumulation of eribulin in the tumor after multiple dosing because of the variability associated with estimating $t_{1 / 2}$ and AUC from time 0 to infinity $\left(\mathrm{AUC}_{0 \text {-inf }}\right)$.

The BPI of eribulin in mice was poor, with exposures ranging from approximately $13-45 \%$ of those observed in plasma after a single dose administration.

\section{Discussion}

PK profiles of eribulin in mice, rats, and dogs were characterized by high volume of distribution, moderate clearance,

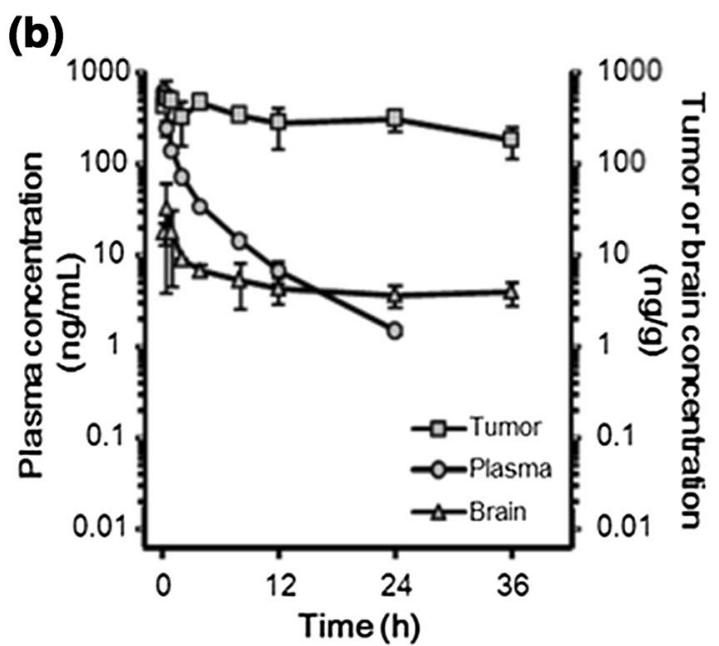

(d)

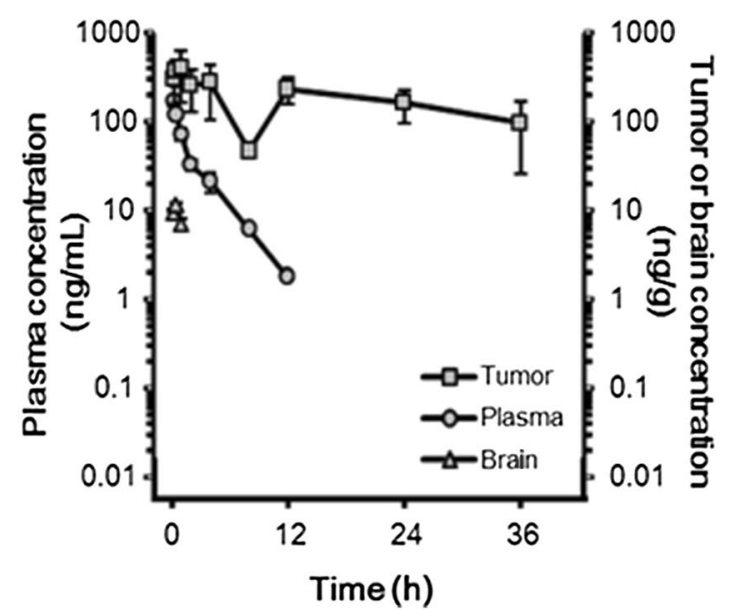

d Q2Dx3* $1.0 \mathrm{mg} / \mathrm{kg}$. *Once every 2 days for three doses. Data are expressed as mean $\pm \mathrm{SD}(n=3)$

and slow elimination. The clearance was similar in the three species. In xenograft female mice, the parameters were similar to those of male BALB/c mice. However, the volume of distribution showed species differences; it was smaller in mice compared with rats and dogs. The reason behind the species differences is uncertain. The disposition profile of eribulin was biphasic, with a rapid distribution phase (within minutes) followed by a long elimination phase. The eribulin half-lives were shorter in mice compared with rats and dogs. The high volume of distribution suggests that eribulin is extensively distributed extravascularly. This is expected due to low protein binding of eribulin and its good membrane permeability. Overall, the PK profiles are similar between animals and humans [11, 12, 19].

In a preclinical study, eribulin showed wide in vivo therapeutic windows [1]. We investigated eribulin exposure in tumor and brain using a xenograft model. Efflux 
transporters, such as P-gp, are expressed in the blood-brain barrier and in cancer cells, which is one of the expected reasons for resistance against anti-cancer chemotherapy [20]. Eribulin is likely to be a P-gp substrate as it shows greater brain penetration in $\mathrm{ABCB}$ memberla-deficient mice than that in wild-type mice [15]. In the present study, the BPI in xenograft mice showed low distribution in brain compared with that in plasma, indicating that eribulin is a P-gp substrate and would have a little effect in the central nervous system. On the other hand, the TPI of eribulin indicated that tumor exposure was approximately 20-30 times higher than that in plasma after both single and multiple dose regimens.

Tumor penetration of other tubulin-binding drugs, such as paclitaxel, in xenograft mice has been well studied. Hamaguchi reported that the TPIs of paclitaxel in colon tumor-bearing mice were 1.07 and 1.49 [21] and those of eribulin in our study were 17.2-33.9. The half-lives of paclitaxel and eribulin in tumor were 7.02-8.06 and 17.8$35.9 \mathrm{~h}$, respectively. These results suggest that eribulin has higher tumor retention than paclitaxel; however, a direct comparison cannot be made as these are different studies evaluating distinct tumor types.

The mechanism of retention in tumor is a balance between distribution and elimination, and depends on both tumor- and drug-specific parameters [22, 23]. Among drugspecific characteristics, a possible reason to explain the high tumor retention of eribulin is related to its mechanism of action. Eribulin showed irreversible mitotic block leading to apoptosis and complete loss of long-term viability at 5 days postwashout [2]. Thus, once eribulin reaches the target tumor cells and binds to high-affinity sites, it will be retained inside the tumor and have persistent activity. Towle et al. also reported that paclitaxel is classified as a drug with reversible activity, suggesting that paclitaxel and eribulin have distinct mechanisms [2].

Additional mechanisms may contribute to a higher distribution of eribulin into tumor tissues. Eribulin was reported to have an effect on vascular normalization and reoxygenation. Eribulin-induced remodeling of vasculature leads to uniform tumor perfusion across all tumor regions in human breast cancer [6] and soft tissue sarcoma [24]. Tumor microenvironment is abnormal compared with that of nonmalignant tissues, and eribulin-induced increased tumor perfusion increased the ability of subsequently administered drugs to reach tumor areas that had previously been poorly perfused. Overall, the high TPI of eribulin, in combination with its diverse mechanism of action, would account for its balanced profile of efficacy and safety.

In the clinical study, eribulin also showed longer activity in tumor [19]. Significant morphologic changes (bundle formation), induced by eribulin, were observed in the microtubules of peripheral blood mononuclear cells and tumor cells in vivo for at least $24 \mathrm{~h}$, and the plasma concentrations of eribulin are maintained well above the levels required for the activity in vitro (sub-nM) for $>72 \mathrm{~h}$ [19]. Regarding retention of higher concentration, the limited metabolism of eribulin would contribute to slow elimination in humans. Furthermore, the vascular remodeling effect of eribulin observed in preclinical studies was also confirmed in clinical studies. Optical imaging technology revealed that oxygen saturation was increased in tumors after eribulin infusion, suggesting that eribulin induces tumor reoxygenation and perfusion [5]. Thus, the recovery of tumor perfusion might also contribute to longer retention of eribulin in human.

In conclusion, eribulin was distributed rapidly and eliminated slowly in mice, rats, and dogs. In female xenograft mice, eribulin PK parameters were similar to those of male BALB/c mice. Eribulin exposure was approximately 20-30 times higher in tumor than in plasma after both single and multiple intravenous dose administrations. These results might be caused by eribulin's mechanism of action including increased perfusion in tumor by due to the remodeling effect. The results of the present study may help to explain the well-balanced efficacy and safety of eribulin in clinical studies.

Acknowledgements The authors would like to thank Drs. Raku Shinkyo and Kenzo Muramoto for their fruitful discussion, and Dr. Osamu Asano for providing chemical structures.

Author contributions KC, EL, CD, and ES participated in research design, conducted experiments, and performed data analysis. MS and KK wrote the manuscript. All authors were involved in reviewing and commenting on the manuscript and approved the final manuscript.

\section{Compliance with ethical standards}

Conflict of interest All authors were paid employees of Eisai at the time that the study was conducted.

Ethical approval All applicable international, national, and/or institutional guidelines for the care and used of animals were followed.

Open Access This article is distributed under the terms of the Creative Commons Attribution 4.0 International License (http://creativecommons.org/licenses/by/4.0/), which permits unrestricted use, distribution, and reproduction in any medium, provided you give appropriate credit to the original author(s) and the source, provide a link to the Creative Commons license, and indicate if changes were made.

\section{References}

1. Towle MJ, Salvato KA, Budrow J, Wels BF, Kuznetsov G, Aalfs KK, Welsh S, Zheng W, Seletsky BM, Palme MH, Habgood GJ, Singer LA, Dipietro LV, Wang Y, Chen JJ, Quincy DA, Davis A, Yoshimatsu K, Kishi Y, Yu MJ, Littlefield BA (2001) In vitro and in vivo anticancer activities of synthetic macrocyclic ketone analogues of halichondrin B. Cancer Res 61:1013-1021 
2. Towle MJ, Salvato KA, Wels BF, Aalfs KK, Zheng W, Seletsky BM, Zhu X, Lewis BM, Kishi Y, Yu MJ, Littlefield BA (2011) Eribulin induces irreversible mitotic blockade: implications of cell-based pharmacodynamics for in vivo efficacy under intermittent dosing conditions. Cancer Res 71:496-505

3. Smith JA, Wilson L, Azarenko O, Zhu X, Lewis BM, Littlefield BA, Jordan MA (2010) Eribulin binds at microtubule ends to a single site on tubulin to suppress dynamic instability. Biochemistry 49:1331-1337

4. Dybdal-Hargreaves NF, Risinger AL, Mooberry SL (2015) Eribulin mesylate: mechanism of action of a unique microtubuletargeting agent. Clin Cancer Res 21:2445-2452

5. Ueda S, Saeki T, Takeuchi H, Shigekawa T, Yamane T, Kuji I, Osaki A (2016) In vivo imaging of eribulin-induced reoxygenation in advanced breast cancer patients: a comparison to bevacizumab. Br J Cancer 114:1212-1218

6. Funahashi Y, Okamoto K, Adachi Y, Semba T, Uesugi M, Ozawa Y, Tohyama O, Uehara T, Kimura T, Watanabe H, Asano M, Kawano S, Tizon X, McCracken PJ, Matsui J, Aoshima K, Nomoto K, Oda Y (2014) Eribulin mesylate reduces tumor microenvironment abnormality by vascular remodeling in preclinical human breast cancer models. Cancer Sci 105:1334-1342

7. Yoshida T, Ozawa Y, Kimura T, Sato Y, Kuznetsov G, Xu S, Uesugi M, Agoulnik S, Taylor N, Funahashi Y, Matsui J (2014) Eribulin mesylate suppresses experimental metastasis of breast cancer cells by reversing phenotype from epithelial-mesenchymal transition (EMT) to mesenchymal-epithelial transition (MET) states. Br J Cancer 110:1497-1505

8. Cortes J, O'Shaughnessy J, Loesch D, Blum JL, Vahdat LT, Petrakova K, Chollet P, Manikas A, Diéras V, Delozier T, Vladimirov V, Cardoso F, Koh H, Bougnoux P, Dutcus CE, Seegobin S, Mir D, Meneses N, Wanders J, Twelves C (2011) Eribulin monotherapy versus treatment of physician's choice in patients with metastatic breast cancer (EMBRACE): a phase 3 open-label randomised study. Lancet 377:914-923

9. Twelves C, Cortes J, Vahdat LT, Wanders J, Akerele C, Kaufman PA (2010) Phase III trials of eribulin mesylate (E7389) in extensively pretreated patients with locally recurrent or metastatic breast cancer. Clin Breast Cancer 10:160-163

10. Schöffski P, Chawla S, Maki RG, Italiano A, Gelderblom H, Choy E, Grignani G, Camargo V, Bauer S, Rha SY, Blay JY, Hohenberger P, D'Adamo D, Guo M, Chmielowski B, Le Cesne A, Demetri GD, Patel SR (2016) Eribulin versus dacarbazine in previously treated patients with advanced liposarcoma or leiomyosarcoma: a randomised, open-label, multicentre, phase 3 trial. Lancet 387:1629-1637

11. Goel S, Mita AC, Mita M, Rowinsky EK, Chu QS, Wong N, Desjardins C, Fang F, Jansen M, Shuster DE, Mani S, Takimoto CH (2009) A phase I study of eribulin mesylate (E7389), a mechanistically novel inhibitor of microtubule dynamics, in patients with advanced solid malignancies. Clin Cancer Res 15:4207-4212

12. AR, Rubin EH, Walton DC, Shuster DE, Wong YN, Fang F, Ashworth S, and Rosen LS (2009) Phase I study of eribulin mesylate administered once every 21 days in patients with advanced solid tumors. Clin Cancer Res 15: 4213-4219

13. Mukohara T, Nagai S, Mukai H, Namiki M, Minami H (2012) Eribulin mesylate in patients with refractory cancers: a phase I study. Investig New Drugs 30:1926-1933

14. Dubbelman AC, Rosing H, Jansen RS, Mergui-Roelvink M, Huitema AD, Koetz B, Lymboura M, Reyderman L, LopezAnaya A, Schellens JH, Beijnen JH (2012) Mass balance study of $\left[{ }^{14} \mathrm{C}\right]$ eribulin in patients with advanced solid tumors. Drug Metab Dispos 40:313-321

15. Taur JS, DesJardins CS, Schuck EL, Wong YN (2011) Interactions between the chemotherapeutic agent eribulin mesylate (E7389) and P-glycoprotein in CF-1 abcbla-deficient mice and Caco-2 cells. Xenobiotica 41:320-326

16. FDA CDER (2005) Estimating the maximum safe starting dose in initial clinical trials for therapeutics in adult healthy volunteers. Guidance for industry. http://www.fda.gov/downloads/ Drugs/Guidances/UCM078932.pdf. Accessed 28 June 2017

17. Desjardins C, Saxton P, Lu SX, Li X, Rowbottom C, Wong YN (2008) A high-performance liquid chromatography-tandem mass spectrometry method for the clinical combination study of carboplatin and anti-tumor agent eribulin mesylate (E7389) in human plasma. J Chromatogr B Analyt Technol Biomed Life Sci 875:373-382

18. Dean RB, Dixion WJ (1951) Simplified statistics for small numbers of observations. Anal Chem 23(4):636-638

19. Morgan RJ, Synold TW, Longmate JA, Quinn DI, Gandara D, Lenz HJ, Ruel C, Xi B, Lewis MD, Colevas AD, Doroshow J, Newman EM (2015) Pharmacodynamics (PD) and pharmacokinetics (PK) of E7389 (eribulin, halichondrin B analog) during a phase I trial in patients with advanced solid tumors: a California Cancer Consortium trial. Cancer Chemother Pharmacol 76:897-907

20. International Transporter Consortium, Giacomini KM, Huang SM, Tweedie DJ, Benet LZ, Brouwer KL, Chu X, Dahlin A, Evers R, Fischer V, Hillgren KM, Hoffmaster KA, Ishikawa T, Keppler D, Kim RB, Lee CA, Niemi M, Polli JW, Sugiyama Y, Swaan PW, Ware JA, Wright SH, Yee SW, Zamek-Gliszczynski MJ, Zhang L (2010) Membrane transporters in drug development. Nat Rev Drug Discov 9:215-236

21. Hamaguchi T, Matsumura Y, Suzuki M, Shimizu K, Goda R, Nakamura I, Nakatomi I, Yokoyama M, Kataoka K, Kakizoe T (2005) NK105, a paclitaxel-incorporating micellar nanoparticle formulation, can extend in vivo antitumour activity and reduce the neurotoxicity of paclitaxel. Br J Cancer 92:1240-1246

22. Jang SH, Wientjes MG, Lu D, Au JL (2003) Drug delivery and transport to solid tumors. Pharm Res 20:1337-1350

23. Rochat B (2009) Importance of influx and efflux systems and xenobiotic metabolizing enzymes in intratumoral disposition of anticancer agents. Curr Cancer Drug Targets 9:652-674

24. Kawano S, Asano M, Adachi Y, Matsui J (2016) Antimitotic and non-mitotic effects of eribulin mesilate in soft tissue sarcoma. Anticancer Res 36:1553-1562 